\title{
Expression of E-cadherin and Ki-67 in canine apocrine and sebaceous gland tumors
}

\author{
Marko Hohšteter, Ivan-Conrado Šoštarić-Zuckermann*, Ivana Mihoković Buhin, Lidija \\ Medven Zagradišnik, Branka Artuković, Ana Beck, and Andrea Gudan Kurilj
}

Department of Veterinary Pathology, Faculty of Veterinary Medicine, University of Zagreb, Zagreb, Croatia

\begin{abstract}
HOHŠTETER, M., I.-C. ŠOŠTARIĆ-ZUCKERMANN, I. MIHOKOVIĆ BUHIN, L. MEDVEN ZAGRADIŠNIK, B. ARTUKOVIĆ, A. BECK, A. GUDAN KURILJ: Expression of E-cadherin and Ki-67 in canine apocrine and sebaceous gland tumors. Vet. arhiv 91, 51-63, 2021.
\end{abstract}

\section{ABSTRACT}

A histopathological analysis of 13 apocrine gland tumors and 22 sebaceous gland tumors in dogs was performed, which were submitted to the Department of Veterinary Pathology from 1 January 2010 to 31 December 2012. An association between the immunohistochemical expression of E-cadherin and Ki-67, the type, and the biological behavior of the tumors was investigated. The mean age of dogs with apocrine gland tumors was 10.15 years, and 10.91 years for sebaceous gland tumors. According to the histopathological analysis, $53.8 \%$ carcinomas and $46.2 \%$ adenomas of the apocrine glands were found. In the sebaceous gland tumors, epitheliomas were dominant (50.0\%), followed by adenomas $(36.4 \%)$ and carcinomas $(13.6 \%)$. Survival time in dogs with sebaceous gland tumors was shortest in patients with diagnosed epitheliomas, intermediate in adenomas, and longest in carcinomas. The incidence of metastases was low in the groups with sebaceous adenomas and epitheliomas, and recurrence was most common in carcinomas. The average survival time was about the same for apocrine gland adenomas and carcinomas, with a higher incidence of metastases and recurrence for carcinomas. Immunohistochemical analysis of E-cadherin and Ki-67 expression confirmed the efficiency of this method for the accurate histological classification of apocrine and especially sebaceous gland tumors. The analyzes performed showed that the location and intensity of E-cadherin expression can be helpful in predicting the biological behavior of sebaceous gland tumors. In contrast to sebaceous gland tumors, the analysis of apocrine gland tumors showed that there was no correlation between E-cadherin expression and the biological behavior of apocrine gland tumors.

Key words: tumor; apocrine gland; sebaceous gland; E-cadherin; Ki-67

\section{Introduction}

Skin tumors are the most common neoplasia in dogs and one of the most frequent causes of death (DOBSON et al., 2002; ŠOŠTARIĆZUCKERMANN et al., 2013; GRÜNTZIG et al., 2015). Sebaceous gland tumors account for $6-7 \%$ and apocrine gland tumors for $3.4-5.1 \%$ of all canine

skin tumors (SIMKO et al., 2003; GROSS et al., 2005; HARGIS and GINN, 2008). On the basis of histological classification and biological behavior, these tumors are classified as benign adenomas (AGA) and malignant apocrine gland carcinomas (AGC). In the group of sebaceous gland neoplasms,

*Corresponding author:

Assist. Prof. Ivan-Conrado Ššstarić-Zuckermann, PhD, DVM, Department of Veterinary Pathology, Faculty of Veterinary Medicine, University of Zagreb, 10000 Zagreb, Heinzelova 55, Croatia, Phone: +385 12390 314; Fax: +385 12441 390; E-mail: ivan_conrado@yahoo.com 
besides adenoma (SGA) and the carcinomas (SGC), there is a third type of semimalignant neoplasias called epitheliomas (SGE) (GOLDSCHMIDT et al., 1998; GOLDSCHMIDT and HENDRICK, 2002; GROSS et al., 2005; HARGIS and GINN, 2008).

Although histopathological analysis is the most important and accurate method for cancer diagnosis, identification of tumor type and estimation of biological behavior and prognosis, there are sometimes difficulties with histopathological analysis (MORRISS and DOBSON, 2001; SABATTINI et al., 2015). The determination of biological behavior can be particularly difficult in the case of well-differentiated carcinomas and tumor types that, apart from the malignant and benign types, have semi-malignant variants, such as the cases with sebaceous gland tumors (GOLDSCHMIDT and HENDRICK, 2002; GROSS et al., 2005). There is a need for additional diagnostic methods to determine the tumor types and to estimate the biological behavior.

Immunohistochemical studies of canine apocrine gland and sebaceous gland tumors show the expression of cytokeratin markers, which are important for the determination of poorly differentiated tumor types. It may also serve a prognostic purpose, e.g. the expression of proliferation markers, such as Ki-67 (GUDAN KURILJ et al., 2011; SABATTINI et al., 2015).

There are some data in the recent literature that show that immunohistochemical analysis of E-cadherin expression may be helpful in diagnosing and estimating the biological behavior of some human and animal tumors (WIJNHOVEN et al., 2000; POLTON et al., 2007; RESTUCCI et al., 2009; HAN et al., 2013; SHAMIR and EWALD, 2015; KARABOLOVSKI et al., 2015)). E-cadherin is a transmembrane protein involved in the adhesion of epithelial cells and extracellular matrix. The reduced or abnormal expression of E-cadherin (cytoplasmic, nonmembranous) leads to the weak interconnection of tumor cells, and facilitates the infiltration of tumor cells into the surrounding tissue. It is consequently associated with a higher malignancy grade and the shorter survival time of human and canine patients with different tumors
(WIJNHOVEN et al., 2000; POLTON et al., 2007; RESTUCCI et al., 2009; SHAMIR and EWALD, 2015; KARABOLOVSKI et al., 2015).

The aim of this study was to test the existence of a correlation between the immunohistochemical expression of E-cadherin and $\mathrm{Ki}-67$ with the histopathological type of tumors, and the biological behavior of tumors, primarily to investigate the correlation with survival time, tumor recurrence rate and metastasis rate. This type of analysis has not yet been performed for E-cadherin expression in sebaceous and apocrine gland tumors in dogs. According to the results of several studies on tumors in humans and dogs (WIJNHOVEN et al., 2000; POLTON et al., 2007; RESTUCCI et al., 2009; KARABOLOVSKI et al., 2015; SABATTINI et al, 2015; BHARDWAJ et al., 2019), the hypothesis of this research was that in more malignant apocrine and sebaceous gland tumors the expression of E-cadherin is weaker and changed from membranous to cytoplasmic and, in contrast, $\mathrm{Ki}-67$ expression is higher in malignant versus benign tumor types.

\section{Materials and methods}

Histopathological analysis. The study was performed on samples of canine apocrine and sebaceous gland tumors presented for histopathological analysis at the Department of Veterinary Pathology of the Faculty of Veterinary Medicine of the University of Zagreb, collected in the period from January 1, 2010 to December 31, 2012. The samples were from animals that were surgically treated at the Clinics of the Faculty of Veterinary Medicine, Zagreb, and in private practices throughout Croatia. The samples were fixed in 10\% neutral buffered formalin and then embedded in paraffin wax, and $5 \mu \mathrm{m}$ sections were stained with hematoxylin and eosin (H\&E) for routine histopathological examination. The H\&E stained sections of the tissues were classified by two experienced pathologists, according to the diagnostic criteria proposed by the World Health Organization (WHO) (GOLDSCHMIDT et al., 1998).

Immunohistochemistry. Immunohistochemical analysis was performed on $5 \mu \mathrm{m}$ sections of 
paraffin-embedded tissue samples. The sections were dewaxed in xylene, and rehydrated by a series of graded alcohol solutions. Antigen retrieval was performed by microwave treatment with citrate buffer $\mathrm{pH} 6$ (Dako REALTM Target Retrieval Solution, code S2031) for 20 minutes. Endogenous peroxidase activity was blocked by incubating the slides for 5 minutes at room temperature in Dako REAL TM-Peroxidase Blocking Solution (DakoCytomation, code S2023). The sections were incubated with primary antibodies for 30 minutes, with the monoclonal mouse anti-E-cadherin antibody (E-cadherin, clone NCH-38, code M3612, DAKO) diluted 1:50 and the mouse anti-Ki-67 monoclonal antibody (Ki-67, clone MIB -1, code M7240, DAKO) diluted 1:100. This was followed by incubation of $30 \mathrm{~min}$ with a ready-to-use secondary antibody (Dako REALTM En VisionTM/ HRP, Rabbit/Mouse), and with the substrate Dako REAL TM Diaminobenzidine + Chromogen for another $10 \mathrm{~min}$. Between each step, rinsing was performed with DakoCytomation Wash Buffer. The sections were counterstained with hematoxylin and mounted. Sections from the normal canine circumanal gland were used as the positive control for E-cadherin, and the substitution of the primary antibody by citrate buffered saline solution was used as the negative control.

The evaluation of the immunohistochemical reaction of E-cadherin was performed semiquantitatively for each tumor. The percentage of positive staining, intensity and cellular localization of the reaction were evaluated. The percentage of tumor cells with positive staining was estimated as a positivity score, and graded from 1 to 3 . One point corresponded to less than $25 \%$ staining, 2 points $25-75 \%$, and 3 points indicated that more than $75 \%$ of the tumor cells showed positive staining. The staining intensity was evaluated as $0=$ negative, $1=$ moderate staining, $2=$ strong staining. The localization was classified as follows: $-1=$ cytoplasmic and $1=$ membranous. On the basis of the total quantification for each tumor, all values were added together to obtain the total score (SUM) of the immunohistochemical reaction (RESTUCCI et al., 2009; ŠOŠTARIĆ-ZUCKERMANN et al., 2016). The Ki-67 reaction was evaluated by determining the proliferation index, expressed as a percentage of Ki-67-positive cells. This was done by counting 1000 cells in 10 high power fields $(400 \mathrm{x})$, and determining the percentage of $\mathrm{Ki}-67$ positive cells.

Analysis of the biological behavior of the tumors. In order to analyze the biological behavior of the tumors, information was collected by telephone interviews with the dogs' veterinarians and/or owners, including survival time after tumor removal, the occurrence of metastases and the recurrence of the tumor at the site of removal. The survival time was rated as survival grades: 1: for animals that survived up to 12 months after tumor removal, 2: 12-24 months, 3: 24-36 months, and 4: for animals that survived more than 36 months after tumor removal. The occurrence of metastases was rated 1 , the absence of metastases 0 . Tumor recurrence at the site of removal was rated with 1 and the non-recurrence 0 .

Statistical analysis. The data collected in the survey were statistically analyzed using the computer program STATISTICA (Data Analysis Software System), StatSoft, Inc. (2011), version 10 www.statsoft.com. The differences between tumor type and the results of immunohistochemical and biological behavioral analysis were tested using the Pearson Hi-square Test. Statistical hypotheses were tested at the significance level of $\mathrm{P}=0.05$, i.e. the difference between samples was considered significant if $\mathrm{P}<0.05$.

\section{Results}

\section{Sebaceous gland tumors}

The samples of seabaceous gland tumors were obtained from 22 dogs with a mean age of 10.91 years (range: 6 to 16 years). The tumors were diagnosed in $54.5 \%(\mathrm{n}=12)$ males and $45.5 \%(\mathrm{n}$ $=10$ ) females. The most frequently affected breeds were mixed breeds ( $31.8 \% ; n=7)$, Golden Retriever $(27.3 \% ; n=6)$ and English Cocker Spaniel (13.6\%; $\mathrm{n}=3$ ); other breeds were represented with a single case.

Histopathological analysis. Histopathological analysis revealed 11 (50.0\%) SBU, 8 (36.4\%) SGA and $3(13.6 \%)$ SGC. 
M. Hohšteter et al.: Expression of E-cadherin and Ki-67 in canine apocrine and sebaceous gland tumors

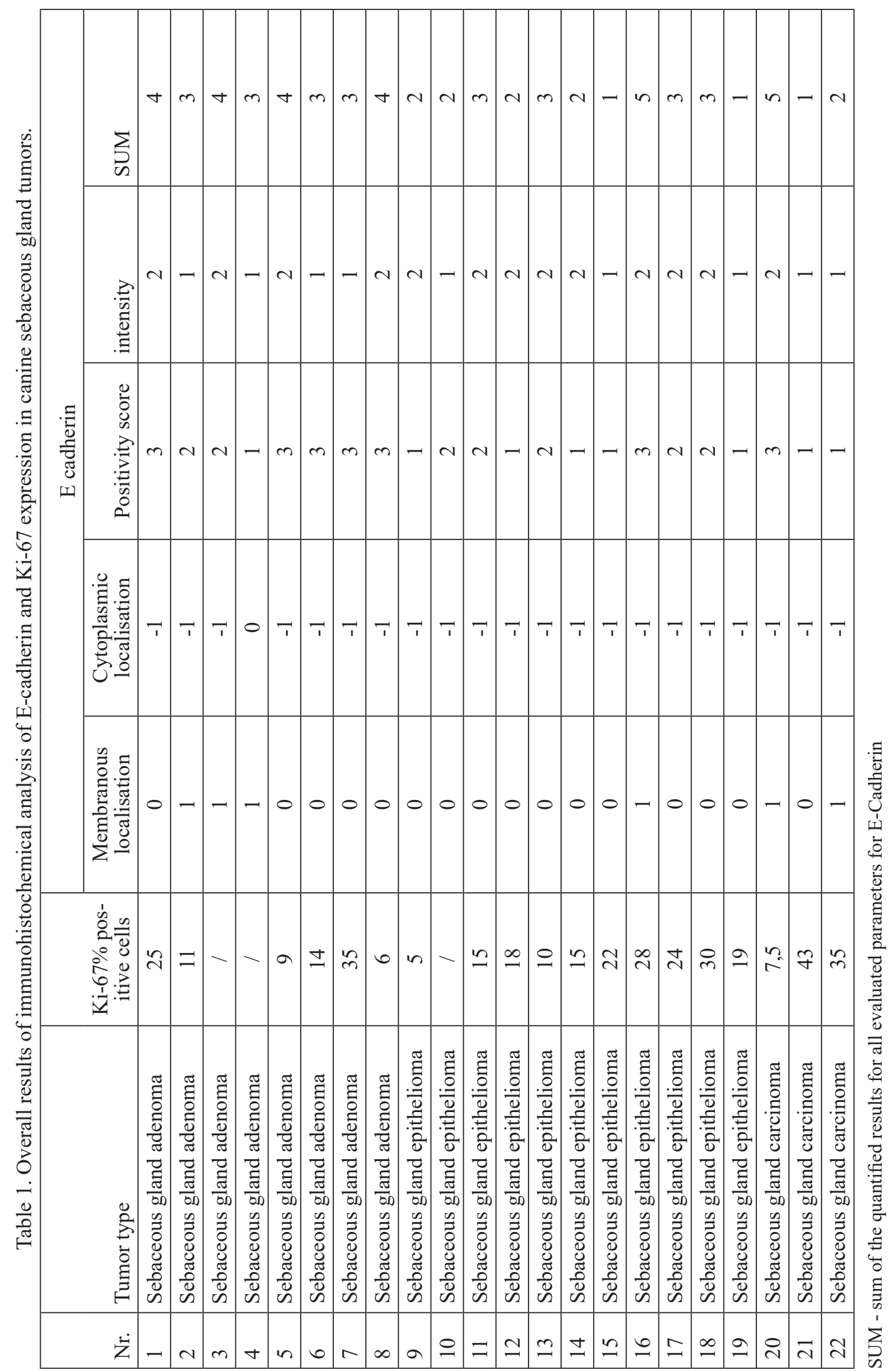


Immunohistochemistry. The results of E-cadherin and $\mathrm{Ki}-67$ expression in sebaceous gland tumors are presented in Table 1.

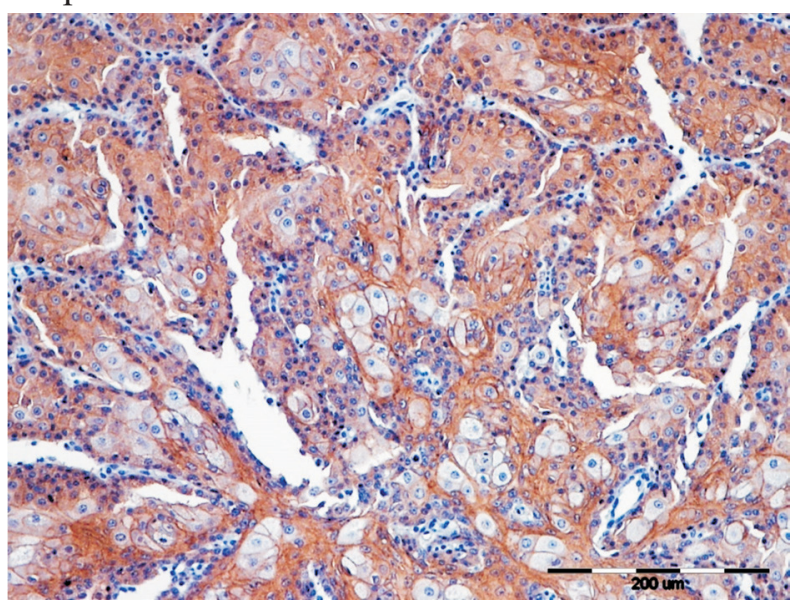

Fig. 1. SGA, dog, diffuse, strong expression of E-cadherin, IHC, E-cadherin, $\times 200$

Sebaceous gland adenoma. The expression of E-cadherin was cytoplasmic in $62.5 \%$ of SGAs, in $12.5 \%$ membranous and in $25.5 \%$ cytoplasmatic and membranous. The mean value of cytoplasmic expression was $-0.86(\mathrm{SD}=0.35)$, and that of membranous expression $0.38(\mathrm{SD}=0.52)$. In $62.5 \%$ of SGAs, E-cadherin was expressed in more than $75 \%$ of cells (Fig. 1), in $25.5 \%$ of adenomas E-cadherin was expressed in $25-75 \%$ of cells, and in $12.5 \%$ of SGAs E-cadherin was expressed in less than $25 \%$ of cells. The mean value of the positivity score was $2.5(\mathrm{SD}=0.76)$. The expression intensity was evaluated as grade 2 in $50 \%$ of the SGAs and as 1 in $50.0 \%$. The mean value of the expression intensity was $1.5(\mathrm{SD}=0.53)$.

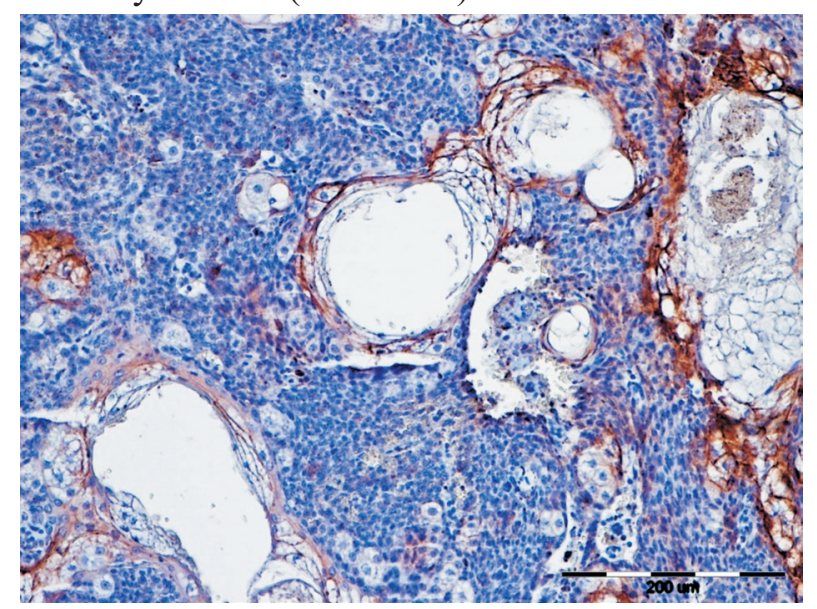

Fig. 2. SGE, dog, low expression of E-cadherin predominantly in differentiated cells, IHC, E-cadherin, $\times 200$

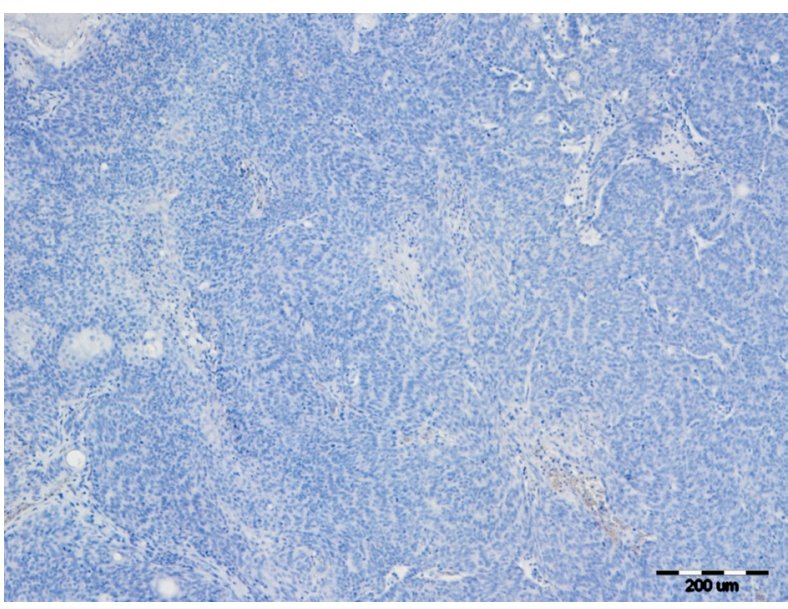

Fig. 3. SGC, low E-cadherin expression; dog, IHC, E-cadherin, $\times 100$

The mean value of $\mathrm{Ki}-67$ proliferation index in SGAs was $16.67 \%$ (SD = 11.11) (Fig. 4a).

Sebaceous gland epithelioma. The expression of E-cadherin (Fig. 2) was cytoplasmic in $90.9 \%$ of SGEs and cytoplasmic and membranous in $9.1 \%$. The mean value of the cytoplasmic expression was $-1(\mathrm{SD}=0)$, that of the membranous expression 0.9 $(\mathrm{SD}=0.3)$. In $45.5 \%$ of epitheliomas, E-cadherin was expressed in less than $25 \%$ of cells, also in $45.5 \%$ of the SGEs it was expressed in $25-75 \%$ of cells, in $9.1 \%$ of SGEs it was expressed in more than $75 \%$ of cells. In $54.5 \%$ of the SGEs E-cadherin was expressed in all tumor cells, and in $45.5 \%$ of the tumors it was expressed only in well-differentiated cells (Fig. 5). The mean value of the positivity score was $1.66(\mathrm{SD}=0.67)$. The expression intensity was evaluated as grade 2 in $72.7 \%$ of the SGEs and as grade 1 in $27.3 \%$. The mean value of the expression intensity was $1.33(\mathrm{SD}=0.58)$.

In the SGEs, the mean value of the Ki-67 proliferation index was $18.6 \%(\mathrm{SD}=7.77)($ Fig. $4 b)$.

Sebaceous gland carcinoma. The expression of E-cadherin was cytoplasmic and membranous in $66.7 \%$ of the SGCs and cytoplasmic in $33.3 \%$. The mean value of the cytoplasmic expression was -1 $(\mathrm{SD}=0)$, that of the membranous expression 0.67 $(\mathrm{SD}=0.58)$. In $66.7 \%$ of the SGCs, E-cadherin was expressed in less than $25 \%$ of cells (Fig. 3 ), and in $33.3 \%$ of the SGCs it was expressed in more than $75 \%$ of cells. 


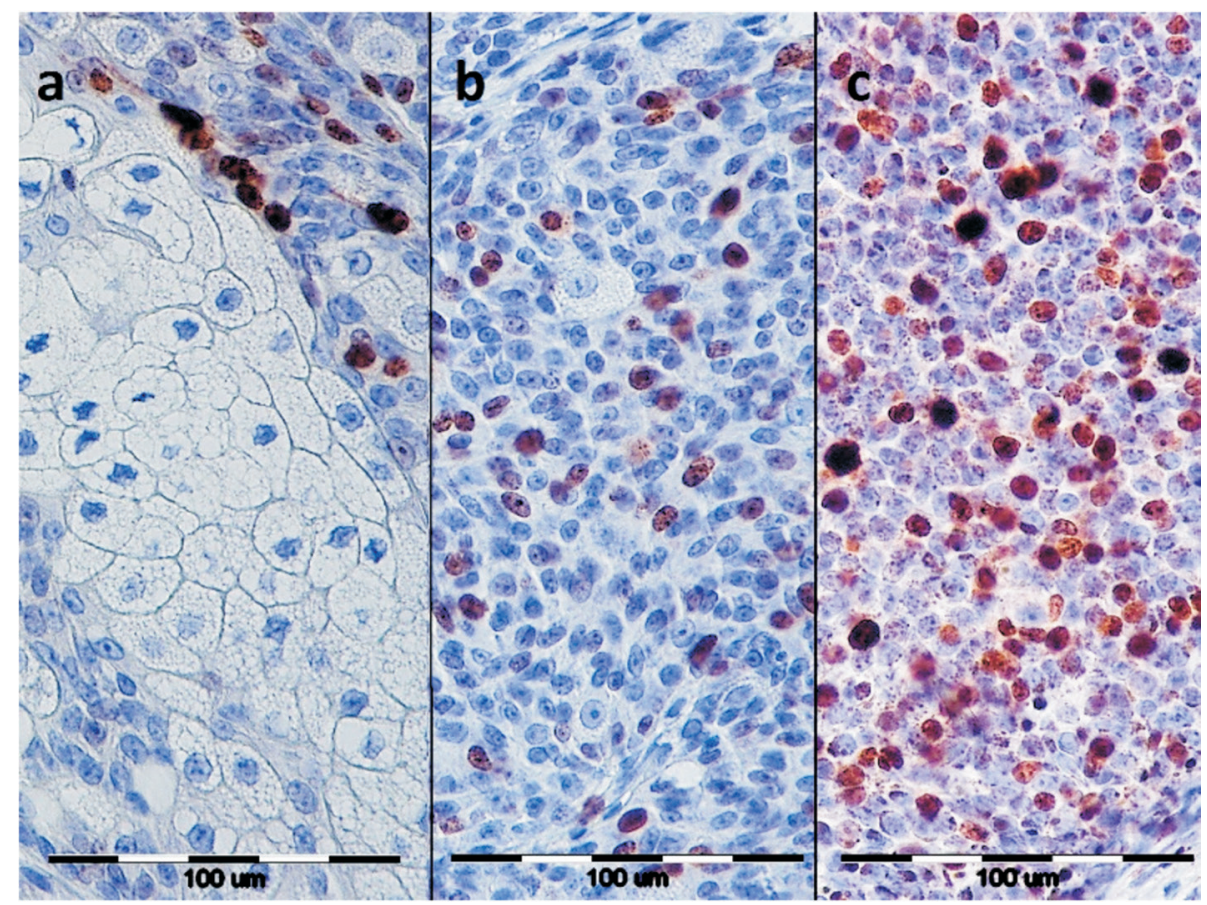

Fig. 4. Sebaceous gland tumors, dogs; a) SGA low Ki-67 expression, b) SGE moderate Ki-67 expression, c) SGC high Ki-67 expression; IHC, Ki-67,×400.

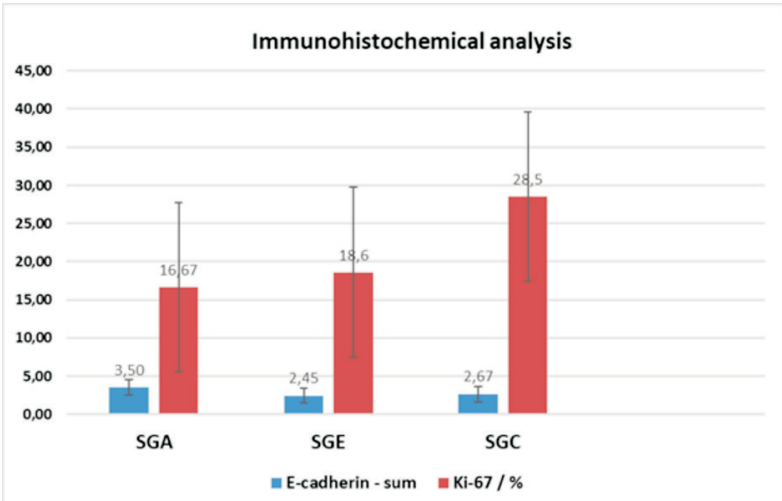

Fig. 5. Mean values and standard deviations of the sum of the quantified results for all evaluated parameters for E-cadherin and Ki-67 proliferation index of SGA, SGE and SGC.

In $66.7 \%$ of the SGCs, E-cadherin was expressed in all tumor cells, and in $33.3 \%$ of the tumors it was expressed only in well-differentiated cells. The mean value of the positivity score was $1.66(\mathrm{SD}=$ 1.15). The expression intensity was evaluated as grade 2 in $66.7 \%$ of the SGCs and as grade 1 in $33.3 \%$. The mean value of the expression intensity was $1.33(\mathrm{SD}=0.58)$.

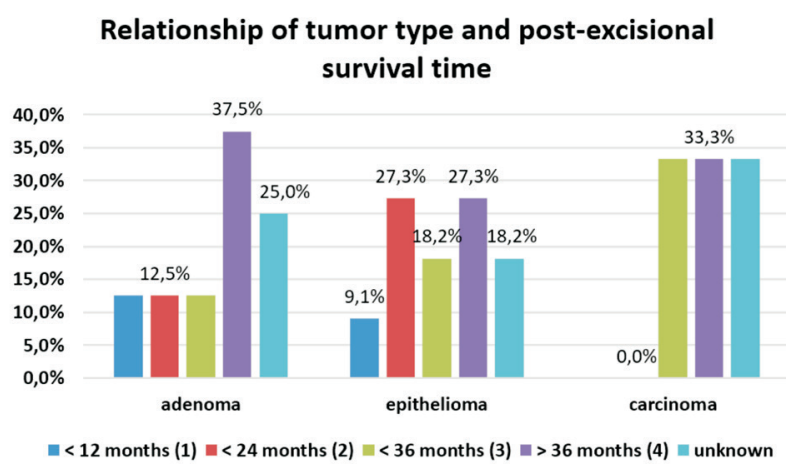

Fig. 6. The relationship of post-excision survival time, expressed as survival grades (1-4) and type of sebaceous gland tumor.

The mean value of the Ki-67 expression represented as a proliferation index was $28.5 \%$ for SGCs $(\mathrm{SD}=18.62)$ (Fig. 4c).

The results of the E-cadherin and Ki-67 analysis for sebaceous gland tumors are shown in Fig. 5 as the sum of all quantified results of the evaluated parameters for E-cadherin and Ki-67. 
Analysis of the biological behavior of the tumors. The average survival rate of the dogs after surgical excisional removal of the tumor was evaluated as follows: SGAs - grade $3.00(\mathrm{SD}=0.71)$; SGEs grade $2.78(\mathrm{SD}=1.093)$, and SGCs - grade $3.50(\mathrm{SD}$ $=0.71$ ). The postoperative survival time of dogs with excised sebaceous gland tumors, expressed as survival grades (1-4), is shown in Fig. 6.

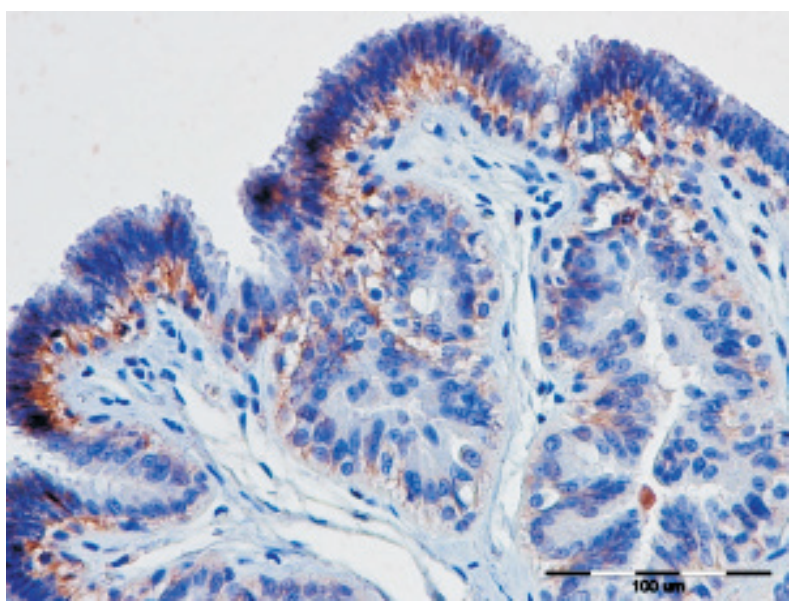

Fig. 7. AGA, dog, expression of E-cadherin in approx. $75 \%$ of tumor cells, IHC, E-cadherin, $\times 400$

The results of the analysis of the metastatic prevalence of sebaceous gland tumors show that the average percentage of metastatic prevalence of tumors histologically diagnosed as SGA was $16.7 \%$ $(\mathrm{SD}=0.41)$, for $\mathrm{SGE} 22.2 \%(\mathrm{SD}=0.44)$ and $\mathrm{SGC}$ $0.00 \%(\mathrm{SD}=0)$. The average percentage of SGA and $\mathrm{SGE}$ recurrence was $33.3 \%(\mathrm{SD}=0.52)$ and for SGC 100\% (SD = 0).

Statistical analysis. The performed statistical analysis (Chi-square test) showed statistically significant differences $(\mathrm{P}=0.04035)$ between different tumor types according to their E-cadherin expression. The analysis showed statistically significant differences between survival times depending on the intensity of E-cadherin expression $(\mathrm{P}=0.041017)$ and also depending on the cytoplasmic distribution of E-cadherin expression $(\mathrm{P}=0.046662)$. The results of the statistical analysis showed no statistically significant differences between different tumor types when correlated with the results of Ki-67 expression and the results of the biological behavioural analysis.

\section{Apocrine gland tumors}

In the three-year period analyzed, 13 samples of apocrine gland tumors were found. The mean age of the dogs was 10.15 years (range: 1 to 16 years). The tumors were diagnosed in $46.1 \%(\mathrm{n}=6)$ males, $38.5 \%(\mathrm{n}=5)$ females, and in $15.4 \%(\mathrm{n}=2)$ the sex was unknown. The most frequently affected breeds were mixed breeds ( $38.5 \% ; \mathrm{n}=5)$, Golden Retrievers $(23.1 \% ; \mathrm{n}=3)$ and German Boxers $(15.4 \% ; n=2)$. Other breeds were represented with single cases.

Histopathological analysis. Histopathological analysis revealed 6 (46.2\%) AGA, and 7 (53.8\%) AGCs.

Immunohistochemistry. The results of E-cadherin and $\mathrm{Ki}-67$ expression in apocrine gland tumors are presented in Table 2.

Apocrine gland adenoma. The expression of E-cadherin was cytoplasmic in 100\% of AGAs (Fig. 7), with a mean value of cytoplasmic expression 1 $(\mathrm{SD}=0)$ and membranous expression $0(\mathrm{SD}=0)$. In $50.0 \%$ of AGAs, E-cadherin was expressed in 25$75 \%$ of the cells (Fig. 11), in $33.3 \%$ of the adenomas E-cadherin was expressed in more than $75 \%$ of the cells, and in $16.7 \%$ of the AGAs E-cadherin was expressed in less than $25 \%$ of the cells. The mean value of the positivity score was $2.17(\mathrm{SD}=0.75)$. The expression intensity was evaluated as grade 2 in $66.7 \%$ of the AGAs and as grade 1 in $33.3 \%$. The mean value of the expression intensity was 1.67 $(\mathrm{SD}=0.52)$.

The mean value of the Ki-67 expression was $7.8 \%$ at $\mathrm{AGA}(\mathrm{SD}=6.02)$.

Apocrine gland carcinoma. The expression of E-cadherin was cytoplasmic in $57.1 \%$ of the AGCs, cytoplasmic and membranous in $28.6 \%$ and membranous in $14.3 \%$. The mean value of cytoplasmic expression was $-0.86(\mathrm{SD}=0.38)$, and that of membranous expression $0.43(\mathrm{SD}=0.53)$. In $57.1 \%$ of AGCs, E-cadherin was expressed in 25$75 \%$ of cells, in $28.6 \%$ of tumors in less than $25 \%$ of cells and in $14.3 \%$ of samples in more than $75 \%$ of cells (Fig. 8). The mean value of the positivity score was $1.86(\mathrm{SD}=0.60)$. The expression intensity was evaluated as grade 1 in $57.1 \%$ of the AGCs and grade 2 in $42.9 \%$. The mean value of the expression intensity was $1.43(\mathrm{SD}=0.53)$. 
M. Hohšteter et al.: Expression of E-cadherin and Ki-67 in canine apocrine and sebaceous gland tumors

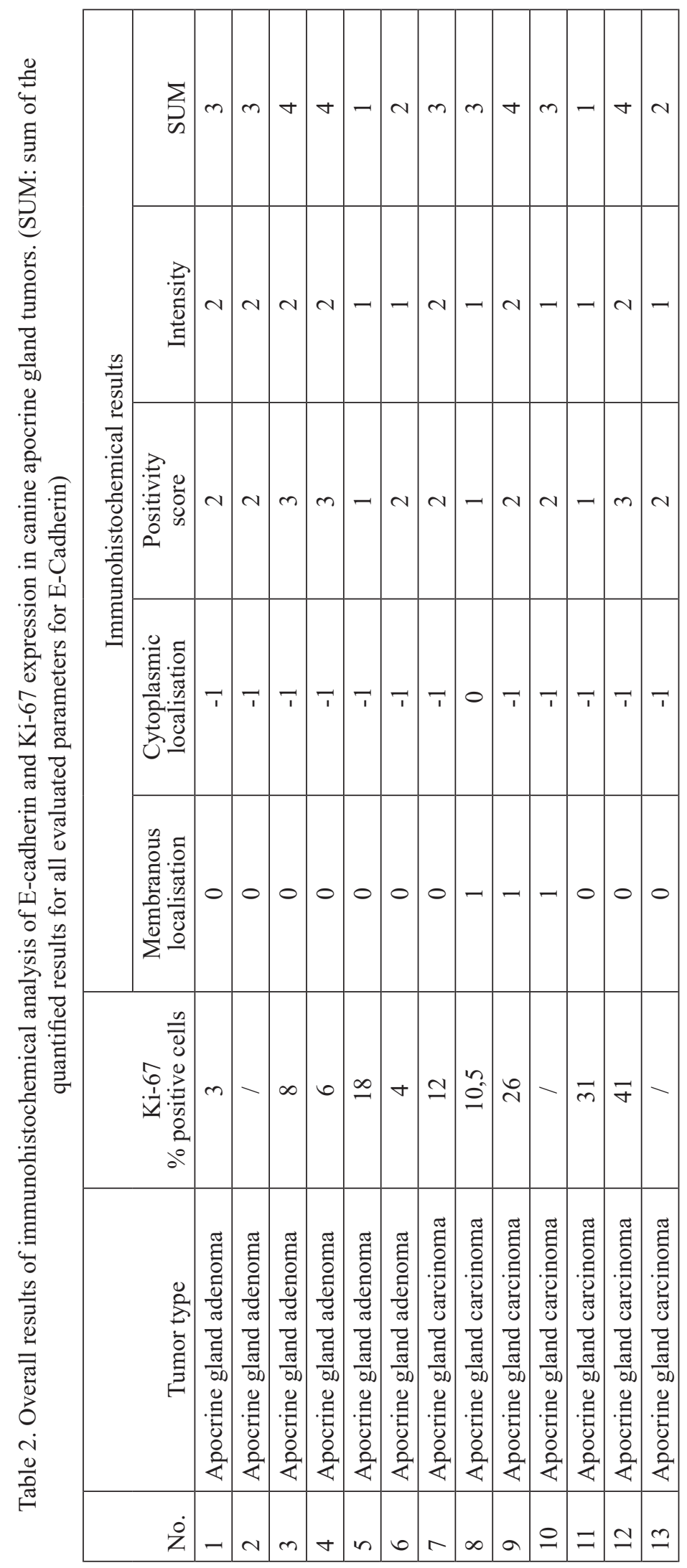


The mean value of Ki-67 expression was $24.1 \%$ in $\mathrm{AGC}(\mathrm{SD}=12.92)$.

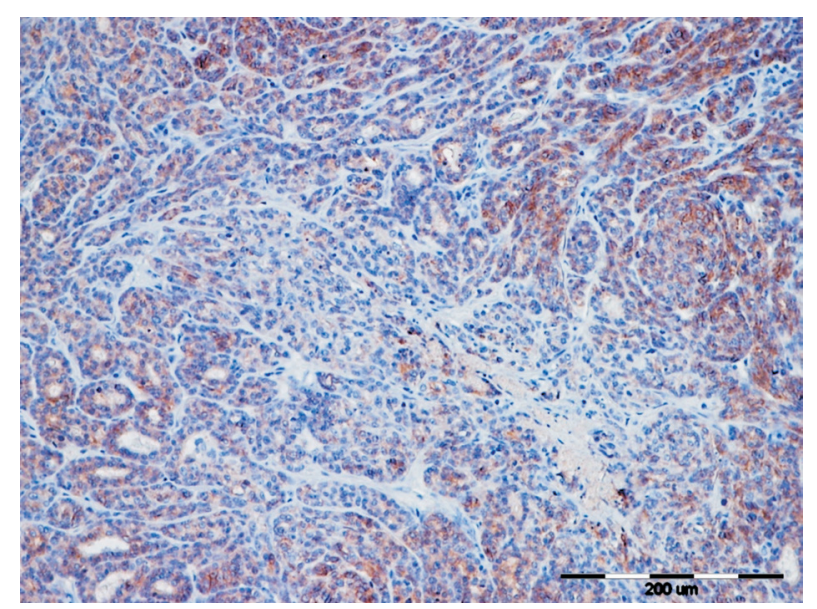

Fig. 8. AGC, dog, expression of E-cadherin in more than $75 \%$ of tumor cells, IHC, E-cadherin, $\times 200$

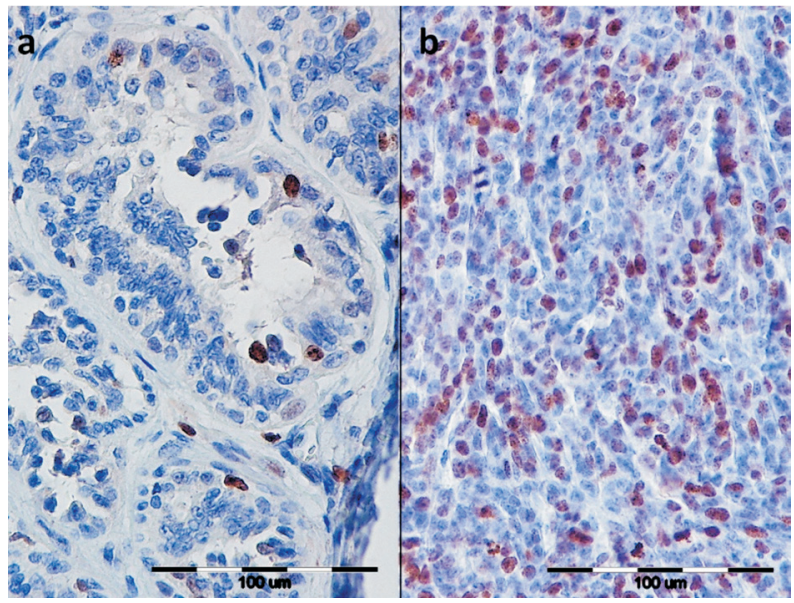

Fig. 9. Apocrine gland tumors, dogs; a) AGA low Ki-67 expression, b) AGC high Ki-67 expression; IHC, Ki-67, $\times 400$.

The results of the E-cadherin and Ki-67 analysis for apocrine gland tumors are shown in Fig.10, as the sum of all the quantified results of the evaluated parameters for E-cadherin and Ki-67.

Analysis of biological behavior of tumors. The average survival grade of the dogs after surgical removal of the tumor was rated for AGAs with a grade of $2.4(\mathrm{SD}=1.41)$ and for the AGCs with $2.33(\mathrm{SD}=1.37)$. The postoperative survival time of dogs with apocrine gland tumors, expressed as survival grades (1-4), is shown in Fig. 11.

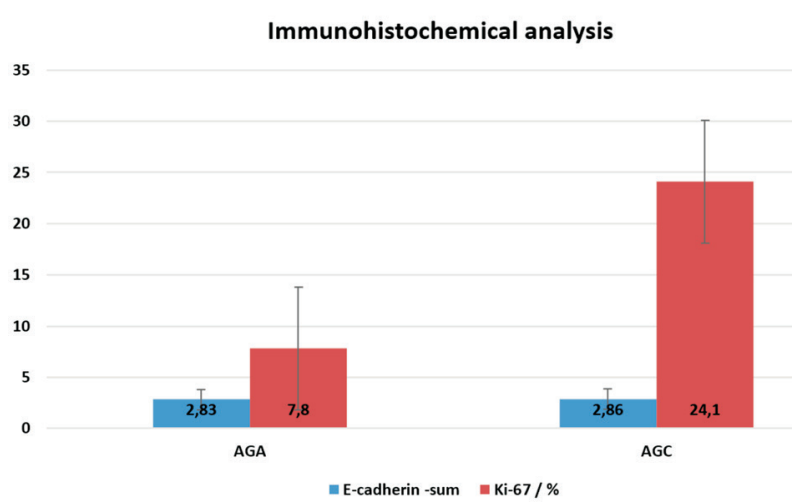

Fig. 10. Mean values and standard deviations of the sum of the quantified results for all evaluated parameters for E-Cadherin and Ki-67 proliferation index from AGAs and AGCs.

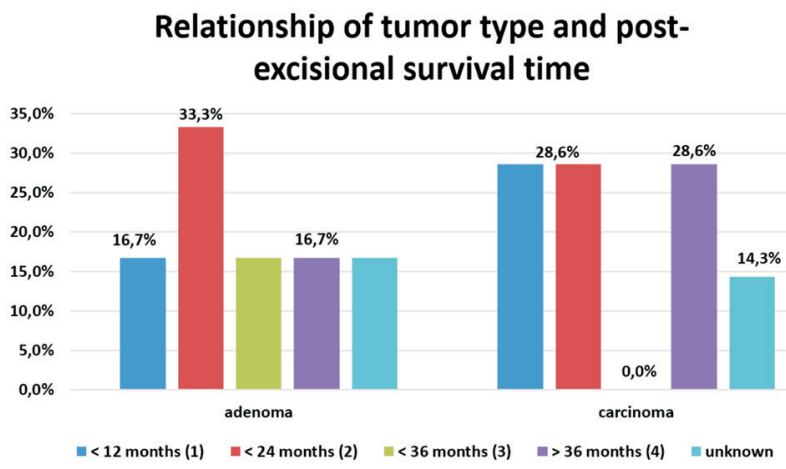

Fig. 11. The relaationship of post-excisional survival time, expressed as survival degrees (1-4) and type of apocrine gland tumor.

The results of the analysis show that no metastases were present in dogs with tumors histologically diagnosed as AGAs, and the prevalence of metastases was $16.7 \%$ in AGCs (SD $=0.41$ ). The average percentage of AGA recurrence rate was $20.0 \%(\mathrm{SD}=0.52)$ and $66.7 \%(\mathrm{SD}=0.52)$ for AGC.

Statistical analysis. The results of statistical analysis (Chi-square test) showed no statistically significant differences between different tumor types when correlated with the results of E-cadherin and Ki-67 expression, and the results of biological behavioural analysis. 


\section{Discussion}

Sebaceous gland tumors. The results of the age and sex analysis of dogs with sebaceous gland tumors are consistent with other studies that show that these tumors occur most frequently in older dogs and that there is no gender-specific predisposition (GROSS et al., 2005). The high prevalence of sebaceous gland tumors in English Cocker Spaniels is also consistent with literature data (GROSS et al., 2005). Furthermore, the histological results with SGEs as the most common and SGCs as a rare tumor types are similar to previous findings (GOLDSCHMIDT i HENDRICK, 2002; GROSS et al., 2005).

The immunohistochemical analysis showed that E-cadherin is expressed least frequently in the cytoplasm of SGAs, most frequently in the cytoplasm of SGEs and with medium frequency in SGCs, when comparing these tumor types. These results are analogous to E-cadherin expression of mammary gland tumors in dogs and some human tumors with membranous expression in benign tumors and cytoplasmic expression in more malignant tumor types (WIJNHOVEN et al., 2000; POLTON et al., 2007; RESTUCCI et al., 2009; KARABOLOVSKI et al., 2015; SHAMIR and EWALD, 2015). The positivity score of E-cadherin expression shows that in histologically benign tumor types (SGA) there were more frequent cases with the highest number of positive tumor cells. The more malignant tumor types (SGE and SGC) express E-cadherin in a smaller percentage. The expression intensity of E-cadherin was highest for SGE and SGC, and lower for SGA. Nevertheless, the number of positive cells was higher in benign tumors, and in malignant tumors, E-cadherin was predominantly expressed in differentiated cells, which are only malignantly transformed to a lesser extent. The mean values of the sum of the quantified results for all evaluated parameters show that the highest value occurred in SGAs after SGEs, and the lowest in SGCs.

On the basis of all the estimated immunohistochemical results it is obvious that the E-cadherin expression is weaker in semimalignant and malignant tumor types (SGEs and SGCs), and in these tumor types the expression is predominantly localized in the cytoplasm, in contrast to benign SGAs. Our results suggest that there is a correlation between immunohistochemical expression of E-cadherin and the histopatological type of sebaceous gland tumor, which is consistent with the results of studies on other tumor types in animals and humans (WIJNHOVEN et al., 2000; POLTON et al., 2007; RESTUCCI et al., 2009; KARABOLOVSKI et al., 2015; SHAMIR and EWALD, 2015). The results of our Ki-67 analysis show that semimalignant and malignant tumor types have a higher Ki-67 proliferation index, which is consistent with the literature data (SABATTINI et al., 2015).

The results of the analysis of biological behavior show that sebaceous gland tumors that are histopathologically assessed as malignant have a worse prognosis, with more frequent metastasis formation and a higher recurrence rate, which is in agreement with the literature data(GOLDSCHMIDT and HENDRICK, 2002; GROSS et al., 2005). The results on survival time are surprising, as survival time was longest in SGCs, but this may be a mere consequence of the very low case numbers within this tumor type $(\mathrm{n}=3)$.

The determination of metastasis in a case of diagnosed SGA, which are tumor types that do not metastasize, indicates that there are difficulties in the histological differentiation of tumor types. There are also possibilities for the classification of semimalignant and malignant tumor types (e.g. SGEs and well differentiated SGCs) into the group of benign tumors, if the differentiation is based on histological analysis only. These results also indicate the need for additional methods to differentiate these tumors.

The results of the statistical analysis, which show statistically significant differences $(\mathrm{P}=$ 0.04035) between the values of the results of E-cadherin expression in different histological types of sebaceous gland tumors, prove our hypothesis that immunohistochemical analysis can be useful as an additional method to determine the type of tumor. These results are compatible with the results of Karabolovski et al (2015) on canine mammary gland tumors. At the same time, the statistical analysis shows statistically significant 
differences $(\mathrm{P}=0.041017)$ between survival time and expression intensity, and statistically significant differences $(\mathrm{P}=0.046662)$ between survival time and the localization of E-cadherin expression. These results suggest opportunities for the application of this immunohistochemical assay as a method to predict survival time in dogs with sebaceous gland adenoma, similar to research on canine apocrine anal sac carcinoma (POLTON et al., 2007).

Apocrine gland tumors. The analysis of the age and sex analysis of dogs with apocrine gland tumors is in agreement with the study by GOLDSCHIMDT and HENDRICK (2002), and shows that there is no gender-specific predisposition and that these tumors occur most frequently in old animals (average age 10.15 years). In our study, apocrine gland tumors occurred most frequently in Golden Retrievers and German Boxers.

The results of our histological analysis show that the incidence of AGAs and AGCs is consistent with the results of other recent studies (SIMKO et al., 2003; GROSS et al., 2005).

Immunohistochemical analyzes showed that E-cadherin was cytoplasmically expressed in all AGAs, whereas the expression was diversely localized in AGCs. There were no differences in immunohistochemical positivity score between different tumor types. The expression intensity of E-cadherin was higher in AGAs and the carcinomas expressed E-cadherin to a lesser extent. The mean values of the sum of the quantified results for all evaluated parameters show that the values for AGAs are approximately the same as for AGCs. These results of the E-cadherin expression analysis are analogous to the results of some studies in dogs and human tumors, suggesting that highly malignant cells express E-cadherin less than benign cells (WIJNHOVEN et al., 2000; POLTON et al., 2007; RESTUCCI et al., 2009; KARABOLOVSKI et al., 2015; SHAMIR and EWALD, 2015). The results for other investigated parameters of immunohistochemical analysis are not compatible with human and animal tumor studies (WIJNHOVEN et al., 2000; POLTON et al., 2007; RESTUCCI et al., 2009; KARABOLOVSKI et al., 2015; SHAMIR and EWALD, 2015). The reasons for this may be a consequence of the small number of tumors analyzed, and the fact that the malignancy of the tumor depends on other factors that differ from the strength of the tumor cell intertwining (CULLEN et al., 2002). The results of the Ki-67 analysis are consistent with SABATTINI et al. (2015) and suggest that malignant apocrine gland tumors have a higher Ki-67 proliferation index.

The results of the biological behavioral analysis show that there are no significant differences in the survival time of dogs with AGAs and AGCs. This is an interesting result for tumor survival time for apocirne gland tumors, as we could not find data for this tumor parameter in the recent literature. The results showing more frequent recurrence and metastasis formation are consistent with other studies conducted for these tumors (SIMKO et al., 2003; GROSS et al., 2005).

The statistical analysis showed no statistically significant differences between different apocrine gland tumor types for the parameters studied, and a possible explanation for this may be associated with the relatively small number of tumors analyzed, and this with the possible errors in obtaining information from the owners through a telephone survey are the weakest points of this study.

Summarising all the results discussed, we conclude that analysis of E-cadherin expression may be useful to determine the exact histopathological type of apocrine gland tumors and especially sebaceous gland tumors in dogs, which can be further supported by Ki-67 analysis. Although immunohistochemical analysis showed no association between E-cadherin and Ki-67 expression and biological behaviour and prognosis in apocrine gland tumors, the study performed shows an association between the intensity and localization of E-cadherin expression and the biological behaviour of sebaceous gland tumors, which may be useful for prognostic assessment in animals with these tumors.

In order to determine more precisely the parameters for estimating the expression of E-cadherin and $\mathrm{Ki}-67$ and the relationship to the biological behavior of apocrine gland tumors and sebaceous gland tumors, studies on the larger number of these tumors are necessary. 


\section{Acknowledgements}

This work was partially supported by FP7-ERA Chairs-Pilot Call-2013, VetMedZg.

\section{References}

BHARDWAJ, M., S. SEN, K. CHOSDOL, S. BAKHSHI, N. PUSHKER, A. SHARMA, S. KASHYAP, M.S. BAJAJ, V.K. SINGH (2019): Vimentin overexpression as a novel poor prognostic biomarker in eyelid sebaceous gland carcinoma. Br. J. Ophthalmol. (0), 1-6.

DOI: 10.1136/bjophthalmol-2018-313285.

CULLEN, J. M., R. PAGE, W. MISDROP (2002): An overview of cancer pathogenesis, diagnosis, and management. In: Tumors in Domestic Animals. (Meuten, D. J. Ed.), Iowa State Press, Iowa, pp. 3-44.

DOBSON, J. M., S. SAMUEL, H. MILSTEIN, K. ROGERS, J. L. WOOD (2002): Canine neoplasia in the UK: estimates of incidence rates from a population of insured dogs. J. Small Anim. Pract. 43, 240-246.

DOI: 10.1111/j.1748-5827.2002.tb00066.x

GOLDSCHMIDT, M. H., R. W. DUNSTAN, A. A. STANNARD, C. VON TSCHARNER, E. J. WALDER, J. A. YAGER (1998): Histologic classification of epithelial and melanocytic tumors of the skin of domestic animals. Armed Forces Institute of Pathology, Washington DC, pp. 26-37.

GOLDSCHMIDT, M. H., M. J. HENDRICK (2002): Tumors of the skin and soft tissues. In: Tumors in Domestic Animals. (Meuten, D. J. Ed.), Iowa State Press, Iowa, pp. 45-117.

GROSS, T. L., P. J. IHRKE, E. J. WALDER, V. K. AFFOLTER (2005): Epithelial neoplasms and other tumors. In: Skin diseases of the dog and cat. Clinical and Histopathologic Diagnosis. $2^{\text {nd }}$ ed., Blackwell Science Ltd, Oxford, pp. 661707.

GRÜNTZIG, K., R. GRAF, M. HÄSSIG, M. WELLE, D. MEIER, G. LOTT, D. ERNI, N. S. SCHENKER, F. GUSCETTI, G. BOO, K. AXHAUSEN, S. FABRIKANT, G. FOLKERS, A. POSPISCHIL (2015): The Swiss Canine Cancer Registry: a retrospective study on the occurrence of tumours in dogs in Switzerland from 1955 to 2008. J. Comp. Pathol. 152, 161-171.

DOI: 10.1016/j.jcpa.2015.02.005

GUDAN KURILJ A., M. HOHŠTETER, B. ARTUKOVIĆ, K. SEVERIN, I. C. ŠOŠTARIĆ-ZUCKERMANN, A. BECK, S. SEIWERTH, R. SABOČANEC, Ž. GRABAREVIĆ (2011): Histopathological evaluation and immunohistochemical study of estrogen receptor $\alpha$, HER2 and Ki-67 in canine neoplastic mammary lesions. Vet. arhiv 81, 709-722.

HAN, J. I., Y. KIM, D. Y. KIM, K. J. NA (2013): Alteration in E-cadherin $/ \beta$-catenin expression in canine melanotic tumors. Vet. Pathol. 50, 274-280.

DOI: $10.1177 / 0300985812457792$
HARGIS, A. M., P. E. GINN (2008): Skin. In: Special veterinary pathology (translated from Croatian) (Grabarević, Ž. Ed.), Stanek, Varaždin, Croatia, pp. 807-961.

KARABOLOVSKI, N., A. GUDAN KURILJ, K. SEVERIN, M. HOHŠTETER, I.-C. ŠOŠTARIĆ-ZUCKERMANN, L. MEDVEN, B. ARTUKOVIĆ, Ž. GRABAREVIĆ (2015): An immunohistochemical study of epithelial-mesenchymal transition in feline mammary tumors. Book of abstract, ESVP-ECVP Annual Meeting, 2-5 September, Helsinki, Finland, p. 138.

MORRIS, J., J. DOBSON (2001): Small Animal Oncology. Blackwell Science Company, Ames, Iowa, USA.

POLTON, G. A., M. J. BREARLEY, L. M. GREEN, T. J. SCASE (2007): Expression of E-cadherin in canine anal sac gland carcinoma and its association with survival. Vet. Comp. Oncol. 5, 232-238.

DOI: 10.1111/j.1476-5829.2007.00131.x

RESTUCCI, B., M. MARTANO, G. DE VICO, L. LO MUZIO, P. MAIOLINO (2009): Ekspression of E-Cadherin, B-Catenin and APC protein in Canine Colorectal Tumors. Anticancer Res. 29, 2919-2926.

SABATTINI, S., P. BASSI, G. BETTINI (2015): Histopathological findings and proliferative activity of canine sebaceous gland tumors with a predominant reserve cell population. J. Comp. Pathol. 152, 145-152.

DOI: 10.1016/j.jcpa.2014.12.011

SHAMIR, E. R., A. J. EWALD (2015): Adhesion in mammary development: Novel roles for E-Cadherin in individual and collective cell migration. Curr. Top. Dev. Biol. 112, 353382.

DOI: $10.1016 /$ bs.ctdb.2014.12.001

SIMKO, E., B. P. WILCOCK, J. A. YAGER (2003): A retrospective study of 44 canine apocrine sweat gland adenocarcinomas. Can. Vet. J. 44, 38-42.

ŠOŠTARIĆ-ZUCKERMANN， I.-C.; K. SEVERIN; M. HUZAK; M. HOHŠTETER; A. GUDAN KURILJ; B. ARTUKOVIĆ; A. DŽAJA; Ž. GRABAREVIĆ (2016): Quantification of morphology of canine circumanal gland tumors: a fractal based study. Eur. J. Histochem. 60, 91-98. DOI: $10.4081 /$ ejh.2016.2609

ŠOŠTARIĆ-ZUCKERMANN, I.-C., K. SEVERIN, M. HOHŠTETER, B. ARTUKOVIĆ, A. BECK, A. GUDAN KURILJ, R. SABOČANEC, P. DŽAJA, Ž. GRABAREVIĆ (2013): Incidence and types of canine tumours in Croatia. Vet. arhiv 83, 31-45.

WIJNHOVEN, B. P. L., W. N. M. DINJENS, M. PIGNATELLI (2000): E-cadherin-catenin cell-cell adhesion complex and human cancer. Br. J. Surg. 87, 992-1005.

DOI: 10.1046/j.1365-2168.2000.01513.x 


\section{HOHŠTETER, M., I.-C. ŠOŠTARIĆ-ZUCKERMANN, I. MIHOKOVIĆ BUHIN, L. MEDVEN ZAGRADIŠNIK, B. ARTUKOVIĆ, A. BECK, A. GUDAN KURILJ: Ekspresija E-kadherina i Ki-67 u tumorima apokrinih i lojnih žlijezda kože pasa. Vet. arhiv 91, 51-63, 2021.}

\section{SAŽETAK}

U radu je istraživana učestalost pojedinih histoloških tipova 13 tumora apokrinih i 22 tumora lojnih žlijezda u pasa čiji su uzorci dostavljeni na histopatološku dijagnostiku na Zavod za veterinarsku patologiju Veterinarskog fakulteta u Zagrebu, u razdoblju od 1. siječnja 2010. do 31. prosinca 2012. godine. Utvrđivano je postoji li povezanost između imunohistokemijske ekspresije E-kadherina i tipa tumora te postoji li povezanost ekspresije E-kadherina i Ki-67 vezano uz biološko ponašanje tumora. Prosječna dob oboljelih životinja iznosila je 10,15 godina za tumore apokrinih žlijezda, a za tumore lojnih žlijezda 10,91 godina. Histopatološkom klasifikacijom tumora ustanovljeno je 53,8 \% karcinoma i 46,2 \% adenoma apokrinih žlijezda, a za tumore lojnih žlijezda 50,0 \% epitelioma, 36,4 \% adenoma te $13,6 \%$ karcinoma. Vrijeme preživljavanja pasa s tumorima lojnih žlijezda bilo je najkraće kod epitelioma, srednje vrijeme preživljavanjea bilo je kod adenoma, a najdulje kod karcinoma. Metastaziranje je potvrđeno kod malog broja adenoma i epitelioma, a učestalost recidiva bila je najveća kod karcinoma lojnih žlijezda. Kod tumora apokrinih žlijezda utvrđeno je približno podjednako vrijeme preživljavanja za adenome i karcinome te češće metastaziranje i recidiviranje karcinoma u odnosu na adenome. Imunohistokemijskom analizom dokazano je da analiza ekspresije E-kadherina i Ki-67 može koristiti u određivanju točnije dijagnoze tipa tumora apokrinih, a osobito tumora lojnih žlijezda pasa. Također, utvrđeno je da kod tumora lojnih žlijezda lokalizacija i intenzitet ekspresije E-kadherina mogu pomoći pri određivanju prognoze, odnosno biološkom ponašanju tumora. Ekspresija E-kadherina u tumorima apokrinih žlijezda pasa u provedenom istraživanju nije pokazala rezultate koji bi upućivali na povezanost rezultata imunohistokemijske pretrage i biološkog ponašanja tumora.

Ključne riječi: tumor; apokrine žlijezde; lojne žlijezde; E-kadherin; Ki-67 
